\title{
The New Literacy of Technopreneurship and Its Relation with Students' Entrepreneurial Spirit
}

\author{
Agung Winarno \\ \{agung.winarno.fe@um.ac.id\} \\ Faculty of Economics Universitas Negeri Malang
}

\begin{abstract}
This study examines a new understanding of technopreneur, which focuses on how students process information and management of knowledge that is reflected in the level of expertise and how it relates to the development of the entrepreneur spirit. Indicators are viewed from aspects of the level of understanding, character, and nature of technopreneur, principles and daily behavior in the utilization of local potential. In terms of quantitative descriptive research, data were collected by employing tests, questionnaires, interviews and review documents. Data analysis uses frequency distribution, t-test, and simple regression. The results showed that the level of Technopreneurship Literacy was high, and entrepreneurial spirit was medium to low. Besides, there was a significant difference in the level of knowledge in which Diploma students were better than that of Undergraduate. The level of understanding of technopreneurship was not related to the development of entrepreneurial spirit.
\end{abstract}

Keywords: Technopreneurship, New Literacy, Entrepreneur Spirit

\section{Introduction}

To actualize the prosperity, increasing the number of entrepreneurs must be a priority. Entrepreneurial contribution to Indonesia's economic growth shows that the micro, small and medium enterprises in gross domestic product increased from 57.84 percent to 60.34 percent in the last five years. At the end of 2010, there were around 53,823,732 (98,85\%) micro, small and medium enterprises from all businesses sectors in Indonesia. The micro, small and medium enterprises (UMKM) are great sectors which have been proven to face the crisis. When Indonesia experienced a crisis in 1998, many large companies or industries went bankrupt, but the existence of micro, small and medium enterprises (UMKM) were still active to face it.

In terms of recruiting employment and decreasing unemployment, entrepreneurs can be the solution. The recruiting labor in this sector increased over the past five years, from 96.99 percent to 97.22 percent [1]. Increasing the number and quality of entrepreneurs has a significant role in the Indonesian economy sector, therefore strengthening effort is needed. The development and growth of micro, small and medium enterprises (UMKM) can be a booster for a country's economic development and growth [2].

As the number of entrepreneurs grows, a new spectrum also develops in the emergence of entrepreneurs. Previously, many entrepreneurs focused on duplicating or modifying businesses that already exist in society. Nowadays, the developments are born in the spectrum of innovation and invention in entrepreneurial growth in Indonesia. The innovation spectrum is an 
entrepreneurial activity that carries out a change or modification of an existing product to create new value added for the product. Meanwhile, the spectrum of the invention is an entrepreneurial activity that produces a new product that has never existed before [2], and it can be achieved if the business world can use technology including the need of the proper legal system, capital markets, and other structural features [3]. In the era of intense business competition, entrepreneurs are required to carry out various maneuvers to become superior. Business innovation must be supported by several types of technological engineering to multiply the performance of the business [4].

In recent years, the term technopreneurship has begun to emerge in Indonesian entrepreneurs community. According to Kompas, it is recorded that $0.24 \%$ from 53 million Indonesian entrepreneurs are technopreneurship. Technopreneurship is the term for technologybased entrepreneurs [5]. Technopreneur is an entrepreneur who understands the technology, creative, innovative, and a brave person who is not afraid of failing the business he is running [6]. If it is seen from the word formation, technopreneurship comes from the word technology and entrepreneurship. Technology in this context is the practical application of science and science into industrial practice. It can also be interpreted as a knowledge framework used to create a tool and system, whereas its development is used to solve an existing business and entrepreneurial problems. Whereas interpreting technopreneurship in the context of intensive technology, is often associated with innovation which is a unification of technology and market needs generated in the creation of relevant value-added products and services [7]. Technopreneurship is a derivative of entrepreneurship that has similarities in the principle of seeking maximum profits, but the emphasis in technopreneurship is on a business that applies a particular technology. It is referred to technology-based entrepreneurship which means technology is used as a tool in the entrepreneurial process. Technology can be a solution to catch on the opportunities. The use of technology in the process of technopreneurship cannot be separated, because technology is used as a means that can facilitate and make entrepreneurial activities more effective and efficient. The awareness for the importance and implementation of technopreneur has been developed in ASEAN countries, for instance in Singapore. There is socialization of prioritizing the movement of creativity and innovation rather than increasing productivity movements, and its movement was carried out by the developing technopreneur in existing companies [8]. It is not so much different from Singapore, in Taiwan there is exclusive development done by national laboratories where the ERSO contributes to the development of human resources associated with the efforts to develop people's creativity through the introduction of modern technology in various business fields [9].

Education is the leading sector to have great generations that are innovative, creative and independent. Building great generations in various changing times are essential so that this nation can win the competition in this global era. Aspects of entrepreneurship continuously strive to be instilled in students, starting from primary education to higher education level [10]. Schools and colleges are essential aspects or means to share knowledge and increase their interest in entrepreneurship. Entrepreneurship is not only related to the intelligence of technical education and skills, but it is also related to the dynamic spirit in facing every challenge and risk which is transformed into potential and opportunity.

Along with the integration between the spirit of entrepreneurship and competence in the field of technology, hopefully, it can be one of the solutions in building great generations who are innovative and independent. Many people want to start a business, but they do not understand how to manage finance; how to market their products; how to develop sales projections for the products they produce [11]. This awareness as developed in the Sultanate of Oman even in the Vision of the 2020 Economic Development Plan emphasized the importance 
of the national movement for the development of technopreneur and encouraged the participation of its citizens in entrepreneurship through various strategies including the education [12]. At the University of Kuala Lumpur, entrepreneurship learning activities among students emphasize the importance of technopreneurship subject because it is considered to be the main factor that can affect not only performance but also the future of the organization [13]. Therefore, technology-based entrepreneurial literacy is an important thing to be instilled in students. This study aims to examine whether there are differences in technopreneurship literacy levels between Diploma program with Bachelor degree students, as well as students from the faculty of economics and engineering, education and non-education studies in East Java.

\section{Method}

This study used a descriptive quantitative approach. The data collection was done by dividing questionnaires, doing interviews, and reviewing the document. The object of the research was 450 students from engineering and economics faculty in diploma and bachelor level, educational and non-educational study programs at various universities in Malang city, East Java. The technopreneur variables in this study were explored with reviews towards the level of the indicator of understanding, character, and nature of technopreneur, principles and daily behavior in the utilization of local potential whereas the entrepreneur spirit was seen from the dimensions of self-confidence, creativity, motivation, attitude to risk and leadership. Besides the frequency distribution, the data analysis also used different tests (t-tests), simple regression, and review of curriculum content.

\section{Findings dan Discussion}

Table 1. Level of technopreneurs literacy and entrepreneur spirit

\begin{tabular}{ccc}
\hline Faculty/Major/Level & Technopreneur Literacy & Entrepreneur Spirit \\
\hline Engineering & High & Low to medium \\
Economics & High & Low to medium \\
Education & High & Low \\
Non-Education & High & Low to medium \\
Diploma & High & Medium to high \\
Undergraduate & High & Low to medium \\
\hline
\end{tabular}

The findings of this study are as shown in table 1 dan 2 below:

Table 2. Differencing Test ( $\mathrm{p}$-value $<0,05)$

\begin{tabular}{lcc}
\hline Faculty/Major/Level & Tecnopreneur Literacy & Entreprenuer Spirit \\
\hline Economics (1) vs Engineering (2) & No different & No different \\
& $(1=2)$ & $(1=2)$ \\
Education (1) vs Non-Education (2) & Different & Different \\
& $(1<2)$ & $(1<2)$ \\
Diploma (1) vs Undergraduate (2) & No different & Different \\
& $(1=2)$ & $(1>2)$ \\
\hline
\end{tabular}

The results of the data description as shown in table 1, it is known that technopreneurship literacy is the majority of respondents $(63.3 \%)$ at all levels in the high category. It showed 
illustration that the awareness of students to follow technological developments related to business is quite good. Whereas the understanding was obtained from the independent learning process from various learning resources in the community, considering that the curriculum does not have a subject dealing with the material. The understanding about technopreneur field from students in both high educational programs could be because students are familiar with technological studies for people's needs. The results also showed that they understand this problem not from the lecturing activities, but from the awareness of the importance of entrepreneurship after observing phenomenon nowadays. Because of students' awareness of the importance of deepening technopreneur subject when the study period was considered as an essential point for starting a business. It is different from the University of Kuala Lumpur, the technopreneur subject is an important subject to be studied at the university, and cultivates awareness on technopreneurship as an essential process which affects not only the performance but also the future of the organization [13]. It is also applied to the students at King Fahd University and universities in Singapore, and the results showed that the education applied had helped the alumni to start start-up business [14].

In table 1, the results of this study showed that spirit entrepreneurs of the students are in the medium category, except for the diploma level that is categorized as high. It can be because students do not explicitly accept lectures with adequate learning content and strategies related to values or spirit in entrepreneurship. In line with the results from previous studies that the entrepreneurship subject in school can only increase knowledge about entrepreneurship, and it is not automatically increasing the spirit of entrepreneurial graduation [10]. Different from Amante's research which found that technopreneurship education significantly showed a high interest in establishing a business themselves [7]. The current function of the education sector is not only limited to create an educated generation but to create an independent generation of nations [2]. Entrepreneurial intentions can be driven by technopreneurship literacy which is a knowledge framework used to create tools to develop expertise and extract material from solving existing problems. In a previous study identified the factors that influence the intention of Student entrepreneurs, it was found that students had a high attitude towards entrepreneurship compared to other factors such as support and resistance, locus of control, need for achievement, intention entrepreneurship, instrumental readiness and subjective norms [15]. High attitudes towards entrepreneurship show that respondents are more supportive of entrepreneurship than organizational work [16]. The results of this research are that the entrepreneur spirit of students was in the medium and low categories, and technopreneurship literacy is quite high. Therefore, it is necessary to be considered seriously by the University so that the entrepreneur spirit of students can increase and be able to create excellent and innovative entrepreneurs. Besides developing an entrepreneurial conscious movement among students, it also needs to follow the example of business development, which is encouraged by university's policies to facilitate this movement and guide the students in finding new ideas, exemplary, informal forums, information on business opportunities, safety nets, market access and executive leadership [3].

\section{Conclusion and Suggestion}

The level of technopreneur literacy of students is high on average, especially in the dimensions of the understanding level, principles, character, and essential traits. Although, it is still relatively low in daily practices. There is no significant difference based on all dimensions of technopreneur literacy between faculties and levels of education, except for education program that is lower in literacy than the non-education program. Entrepreneur spirit of students on average are still moderate and tend to be low, except for the diploma program, and there is 
no significant influence between the level of entrepreneurial literacy and entrepreneur spirit. It is recommended that practicing successful technopreneur-based learning needs to be studied more, and the application of learning models which has entrepreneurial values needs to be internalized. This model is expected to encourage high entrepreneurial spirit of students. Thus, it is necessary to become independent graduates.

\section{References}

[1] Badan Pusat Statistik, 'Data Statistik Perkembangan serapan tenaga kerja sektor umkm', Jakarta, 2016.

[2] S. Marti'ah, 'Kewirausahaan Berbasis Teknologi (Technopreneurship) Dalam Perspektif Ilmu Pendidikan', J. Ilm. Edutic, vol. 3, no. 2, pp. 75-82, 2017.

[3] S. Venkataraman, 'Regional Transformation Through Technological Entrepreneurship', J. Bus. Ventur., vol. 19, no. 1, pp. 153-167, 2004.

[4] Harjono, A. Widyatmoko, and T. Nurhidayat, 'Pembelajaran Kewirausahaan Politama', in Konferensi Nasional "Inovasi dan Technopreneurship”, 2013, pp. 1-5.

[5] Kompas, 'Technopreneur' Langka di Indonesia', Kompas, 2011.

[6] S. I. Wahjono, 'Indonesia dan Technopreneurship', in International Seminar on Technology and Entrepreneurship: Challenge and Opportunity in Indonesia, 2013.

[7] A. D. Amante and T. A. Ronquillo, 'Technopreneurship as an Outcomes-Based Education Tool Applied in Some Engineering and Computing Science Programme', Australas. J. Eng. Educ., vol. 22 , no. 1 , pp. 1-10, 2017.

[8] C. Foo and C. Foo, 'Socialization of Technopreneurism: Towards Symbiosis in Corporate Innovation and Technology Strategy', Technovation, vol. 20, pp. 551-562, 2000.

[9] T. H. Lo, S. Liou, and B. Yuan, 'Organisation Innovation and Entrepreneurship: The Role of The National Laboratories in Promoting Industrial Development', Int. J. Technol. Manag., vol. 30 , no. $1 / 2$, pp. 67-84, 2005.

[10] W. Agung, 'Intensi Kewirausahaan: Perspektif Karakteristik Kepribadian, Pembelajaran d an Jaringan Sosial (Studi pada Mahasiswa Program Akademik dan Vokasi UM)', J. Ekon. Bisnis, vol. 17 , no. 1 , p. $2014,2014$.

[11] A. Winarno, T. Wijijayanti, and Y. Agustina, 'Pioneering an Autonomous Village Through the Management of Sustainable Tourism Village Based on Local Potential in Malang Regency', KnE Soc. Sci., vol. 3, no. 3, 2018.

[12] R. L. R. Maata, R. Al Azawi, I. Masmoudi, and A. S. Al Shaqsi, 'A proposed concept and model to strengthen the implementation of technopreneurship in higher education institutions', in Proceedings of Majan International Conference: Promoting Entrepreneurship and Technological Skills: National Needs, Global Trends, 2018.

[13] Business, 'Technopreneurship', Business, 2009.

[14] King Fahd University of Petroleum \& Mineral, Undergraduate Bulletin 2006-2009. Dhahran: King Fahd University of Petroleum \& Mineral, 2006.

[15] S. C. Mat, S. M. Maat, and N. Mohd, 'Identifying Factors that Affecting the Entrepreneurial Intention among Engineering Technology Students', Procedia - Soc. Behav. Sci., vol. 211, no. September, pp. 1016-1022, 2015.

[16] L. Kolvereid, 'Prediction of Employment Status Choice Intentions', Entrep. Theory Pract., vol. 21, no. 1, pp. 47-58, 1997.

[1] Badan Pusat Statistik, 'Data Statistik Perkembangan serapan tenaga kerja sektor umkm', Jakarta, 2016.

[2] S. Marti'ah, 'Kewirausahaan Berbasis Teknologi (Technopreneurship) Dalam Perspektif Ilmu Pendidikan', J. Ilm. Edutic, vol. 3, no. 2, pp. 75-82, 2017.

[3] S. Venkataraman, 'Regional Transformation Through Technological Entrepreneurship', J. Bus. Ventur., vol. 19, no. 1, pp. 153-167, 2004. 
[4] Harjono, A. Widyatmoko, and T. Nurhidayat, 'Pembelajaran Kewirausahaan Politama', in Konferensi Nasional "Inovasi dan Technopreneurship", 2013, pp. 1-5.

[5] Kompas, 'Technopreneur' Langka di Indonesia', Kompas, 2011.

[6] S. I. Wahjono, 'Indonesia dan Technopreneurship', in International Seminar on Technology and Entrepreneurship: Challenge and Opportunity in Indonesia, 2013.

[7] A. D. Amante and T. A. Ronquillo, 'Technopreneurship as an Outcomes-Based Education Tool Applied in Some Engineering and Computing Science Programme', Australas. J. Eng. Educ., vol. 22 , no. 1, pp. 1-10, 2017.

[8] C. Foo and C. Foo, 'Socialization of Technopreneurism: Towards Symbiosis in Corporate Innovation and Technology Strategy', Technovation, vol. 20, pp. 551-562, 2000.

[9] T. H. Lo, S. Liou, and B. Yuan, 'Organisation Innovation and Entrepreneurship: The Role of The National Laboratories in Promoting Industrial Development', Int. J. Technol. Manag., vol. 30, no. 1/2, pp. 67-84, 2005.

[10] W. Agung, 'Intensi Kewirausahaan: Perspektif Karakteristik Kepribadian, Pembelajaran d an Jaringan Sosial (Studi pada Mahasiswa Program Akademik dan Vokasi UM)', J. Ekon. Bisnis, vol. 17, no. 1, p. 2014, 2014.

[11] A. Winarno, T. Wijijayanti, and Y. Agustina, 'Pioneering an Autonomous Village Through the Management of Sustainable Tourism Village Based on Local Potential in Malang Regency', KnE Soc. Sci., vol. 3, no. 3, 2018.

[12] R. L. R. Maata, R. Al Azawi, I. Masmoudi, and A. S. Al Shaqsi, 'A proposed concept and model to strengthen the implementation of technopreneurship in higher education institutions', in Proceedings of Majan International Conference: Promoting Entrepreneurship and Technological Skills: National Needs, Global Trends, 2018.

[13] Business, 'Technopreneurship', Business, 2009.

[14] King Fahd University of Petroleum \& Mineral, Undergraduate Bulletin 2006-2009. Dhahran: King Fahd University of Petroleum \& Mineral, 2006.

[15] S. C. Mat, S. M. Maat, and N. Mohd, 'Identifying Factors that Affecting the Entrepreneurial Intention among Engineering Technology Students', Procedia - Soc. Behav. Sci., vol. 211, no. September, pp. 1016-1022, 2015.

[16] L. Kolvereid, 'Prediction of Employment Status Choice Intentions', Entrep. Theory Pract., vol. 21, no. 1, pp. 47-58, 1997. 